\title{
Opinions and Levels of Awareness Among Cypriot Society Regarding Children's Rights
}

Panayiotis Angelides, Elena Papanastasiou \& Christina Hadjisoteriou

University of Nicosia

Corresponding Author:

Panayiotis Angelides

46 Makedonitissas Ave

1700 Nicosia

Cyprus

Tel: +357-22841733

Angelides.p@unic.ac.cy 


\begin{abstract}
This article examines the following issues: a) attitudes and awareness levels of the Cypriot society in regard to the contents of the UN Convention on the Rights of the Child; and b) the views of this society regarding (the extent of) the protection of these rights by the State. Research data have been collected from three populations in Cyprus: (a) elementary students aged 9-13 years old; (b) high school students, and (c) university students and adults aged 18 years and older. The sample consisted of 1435 Cypriots who participated in the survey through telephone interviews and questionnaires, as well as 18 individuals (adults) that participated through focus groups and personal interviews. The results show some of the most serious problems of the Cyprus society regarding the rights of children. The perceptions of children do not see the child as a distinct and autonomous personality with inherent rights and dignity. Furthermore, it appears from the data that the competencies of the various bodies related to children's rights are not clear in society and there is confusion among citizens about the responsibilities and competences of each institution.
\end{abstract}

Keywords: Children's rights, Cyprus education, awareness 


\section{Opinions and Levels of Awareness of Children's Rights in Cyprus}

In recent years, efforts to consolidate children's rights have intensified across many countries. The United Nations Convention on the Rights of the Child (UNCRC) (1989) strengthened these initiatives. It is the most widely recognised human rights agreement in the world. The Convention, consisting of 54 articles, is the first global, legally binding document for the rights that all children should enjoy, and is considered as a milestone in the history of human rights globally. It establishes the basic principles defining children's rights to protection, provision and participation across the different stages of their development.

Further, the UNCRC is an international human rights treaty that places emphasis on the child and declares that all children are born with basic freedoms and rights. The Convention delineates the range of rights which should be enjoyed by children wherever they are and obliges States that have ratified the Convention, to make necessary adjustments to their legislative systems in order to protect and guarantee the rights of children at all levels. The obligations of States are detailed in Comment No. 5 of the United Nations Committee on the Rights of the Child (GRC/C/GC/5/2003) that explains the administrative, legislative and other measures that states must take to ensure the rights of children.

The ratification of the UNCRC in 1990 by the Republic of Cyprus indicated the need for changes in regulations and procedures relating to the rights of children. Despite the fact that this happened almost twenty years ago, the Republic has only recently established the institution of the Commissioner for the protection of the rights of the child as an advocacy mechanism for the protection of these rights in 2007.

The role of independent institutions in the various countries on the protection of the rights of children is reviewed in 'General Comment No. 2' (GRC/C/GC/2/2002) which emphasises the importance of these institutions as mechanisms for the promotion and protection of children's rights. Nonetheless, various reports in the Cypriot daily press (e.g. Kyriakidou, 2009; Kassinidou 2009; Chatzibasilis 2009; Panagi, 2009a; 2009b) as well as recent surveys conducted in Cyprus (e.g Authors, 2009; Authors, 2004; Authors, 2004; Messiou, 2006) indicate that children's rights violations continue in Cyprus. 
According to reports in the daily press, children's rights violations occur against children who have been characterised as having disabilities and are thus placed in institutions (Kassinidou, 2009), children who are often abused (Panagi, 2009a; Kyriakidou, 2009) or children who are isolated and marginalised (Panagi, 2009b). In addition, many children are marginalised in schools due to their ethnicity, religion, socio-economic status or disability. One of the conclusions that emerges from these media reports is that awareness of children's rights in schools, and the wider society in Cyprus, appears to be deficient. However, no largescale, comprehensive survey in Cyprus exists that examines the awareness levels of both children and adults regarding children's rights and the potential barriers this lack presents to children. Therefore, the aim of the present study has been to address the aforementioned gap by examining: a) the attitudes and awareness levels of members of Cypriot society with regard to the content of the UNCRC and, b) societal views regarding (the extent of) the safeguarding of these rights by the State. Therefore, this study firstly analyses the issue of children's rights, provides an overview of the methodology used in this study, presents findings, and proposes some suggestions for action to increase awareness and protection of children's rights in Cyprus.

\section{Views of Children's Rights}

At the international level, various surveys have been conducted on children's views of their rights (Bosisio, 2013; Eurobarometer, 2008; Margolin, 1982; Quennerstedt, 2016; Wrightsman, 1975). Comparative studies have been carried out between (a) different countries exploring the views of children, teachers and parents regarding children's rights (Casas et al., 2006; Lundy et al., 2013; Van Daalen et al., 2016), and (b) cultural views of children's rights (Khoury-Kassabri \& Ben-Arieh, 2009; see also, Deb \& Mathews, 2012). Moreover, previous research has also examined the views of university students regarding children's rights (Karaman-Kepenekci, 2006).

A number of surveys deal specifically with children's rights as presented in the UNCRC with the aim to develop new modes of intervention to promote knowledge, recognition and implementation of children's rights in school and society in general. In 2008, Eurobaromater launched a survey in the twenty-seven countries of the European Union for the purposes of determining the extent to which young people (aged 15-18 years) were aware of their rights; the extent to which these rights were protected; and what actions should be developed to improve the protection of children's rights at national and European levels. The 
survey examined the awareness of young people about specific rights, their views on how these rights are protected, their experiences of asking for help to protect their rights, their views about the basic provisions of the laws associated with them, their suggestions on National and European actions which should be undertaken, and on the easiest ways to find information about their rights. The main findings of the Eurobarometer research showed that young people are aware of having specific rights. Nevertheless, they argued that the provision of more information on their rights should be a top priority, while they claimed that such information should be offered through the internet. In general, most young people felt that their rights are protected in their own countries and stressed that the main problems faced by youngsters is violence against children, sexual exploitation of children, and drugs.

A comparative survey conducted in Spain and Italy about the views of children, their parents and their teachers on the rights of the child showed that participants from 60 countries shared similar views with regard to the practical aspects of everyday life that relate to the rights of the child (Casas et al., 2006). For example, there is a shared positive view regarding the integration in mainstream schools of children with disabilities or children who come from foreign countries. Another comparative research project carried out in Israel (KhouryKassabri \& Ben-Arieh, 2009) compared the views of Jews and Arabs (12-14 years) on the rights of the child. This survey is unique in that it examines the views of children about their rights in a non-Western, non-Christian culture. The results showed that young Jews favoured the rights of the child more strongly on a personal level in comparison with young Arabs. The authors interpreted this result as a consequence of the patriarchal character of some families in comparison with the more democratic character of others.

A 2006 Turkish study (Karaman-Kepenekci, 2006) surveyed university students for their views on children's rights. Findings indicate that female students, students of educational departments, and students who attended courses on human rights expressed more positive views on children's rights.

\section{Methodology}

The research data for the current study have been collected from three populations from the Republic of Cyprus: (a) elementary students, aged 9-13 (grades 4-6), (b) high school students, and (c) university students and adults aged 18 years and older. The total sample consisted of 1,435 people who participated in the survey through telephone interviews and 
questionnaires, while an additional sample of 18 adults participated in the study through focus groups and personal interviews. The research data were collected in May and June of 2012 .

Cluster sampling was the method used to collect data from all districts of Cyprus. The percentage of students who took part in the survey by district is shown in Table 1. One hundred ninety-five elementary school students participated in the survey; the average age of students was $10.69(\mathrm{sd}=0.92)$. Males comprised forty-nine per cent of the sample and $51 \%$ female.

Cluster sampling was used with the second population of high school students aged 1318 years.. The sample included 414 students of all grades of high-school and lyceum. The average age of the students was $15(\mathrm{sd}=1.64)$, while $29.8 \%$ of the sample were male and $70.2 \%$ female students.

In order to conduct the study and for children to participate, the study required authorisation from the Ministry of Education and Culture was required to allow questionnaires to be distributed in schools; head-teachers of the participant schools; children's parents, as well as children's willingness to participate in the research.

The overall sample included 826 adults including 195 university students and 631 nonuniversity adults. The sampling of university students drew upon the random selection of entire sections of undergraduate courses in the departments of Education, Social Work and Psychology. These departments were specifically selected due to links between these majors and children. The majority of the university students were women $(87.69 \%)$ which is representative of the population of students in specific disciplines. The selection of other adults was carried out according to proportional sampling in order to achieve coverage of the population of all the districts of Cyprus. Women comprised $50.01 \%$ of the sample.

\section{Interviews and Focus Groups With Adults}

The goal of the interviews (seven interviews) and two focus groups was to collect indepth data regarding children's rights in Cyprus. Initially, focus groups were conducted with key stakeholders selected on the basis of their degree of involvement in children's rights issues (e.g. students, teachers, psychologists, parents, academics and government officials), as well as other people from various strata of society (e.g. prison guards, beauticians). From this sample, seven of the individuals came from upper socio-economic level. Seven additional 
personal interviews were conducted with people without a university education in order to obtain a more representative sample of the Cypriot population.

\section{Results}

Questions on knowledge regarding children's rights comprised the first set of questions administered to the student sample. Results indicate that a majority of students are not aware of the UNCRC's definition of the term 'child.' $22.8 \%$ of the students were aware that the term 'child' referred to individuals aged $0-18$ years. The majority of the participants students (48.8\%) considered the term 'child' to refer to people $0-12$ years, while $28.4 \%$ of the students considered that the term referred to those aged 1-14 years (Table 1). 17.5\% of the participant adults and $42.6 \%$ of the university students knew that the term 'child' defined those $0-18$ years old. It is noteworthy that less than half of the participant university students were not aware of the age range of childhood as defined by the UNCRC. This percentage was higher than the percentage of students in primary and secondary education who were familiar with the definition.

Table 1. Students' knowledge of the definition of the term "child" (Sample size: 609)

\begin{tabular}{|llll|}
\hline $\begin{array}{l}\text { Definition of the } \\
\text { term "child" }\end{array}$ & $\begin{array}{l}\text { Elementary } \\
\text { Students }\end{array}$ & $\begin{array}{l}\text { High-school/ } \\
\text { Lyceum Students }\end{array}$ & $\begin{array}{l}\text { Total number of } \\
\text { students }\end{array}$ \\
\hline $\mathbf{0 - 1 2}$ years old & 48.2 & 49.1 & $\%$ \\
\hline $\mathbf{0 - 1 8}$ years old & 26.2 & 21.2 & 48.8 \\
\hline $\mathbf{1 - 1 4}$ years old & 25.7 & 29.7 & 22.8 \\
\hline
\end{tabular}

Regarding the question, "at what age do children start to have rights?" the majority of students (42.3\%) were aware that children have rights beginning from birth. A small percentage of students $(6.6 \%)$ believed that children begin to have rights from the moment they learn to speak, while $13.2 \%$ of children believed that children begin to have rights from the age of 13 . In contrast, $58 \%$ of the university students and $36.8 \%$ of the other participating adults were aware that children have rights from the moment of birth. It should be noted that 
$16.1 \%$ of the university students thought that children begin having rights when they turn one year old, while $14.5 \%$ thought that rights begin at the age of 18 .

The questionnaire to students also examined inter alia whether students were aware of some of the issues included in the Convention on the Rights of the Child. In general, the majority of the students were aware of their rights, although there were some students who did not know any of them. On average, students were aware of 7.7 of the 17 articles $(\mathrm{sd}=$ 1.6) of the Convention. None of the students answered every question, while only $3.1 \%$ of the sample responded to 16 of the 17 questions correctly (see Table 2).

The prompt to which most students responded incorrectly was that of "children are property (belong) of their parents." Thirty-one per cent of respondents stated that they believed this statement to be correct, while $8.7 \%$ of the students did not know the answer. It is noteworthy that $15.5 \%$ of the students in the sample also believed that "in some cases the parents are entitled to hit their children." Finally, 6.2\% believed that "parents can force their children to work to bring money home." The overall percentages of students' answers on content in the Convention on the Rights of the Child are presented in Table 2.

Table 2. Student's awareness of content in the Convention on the Rights of the Child.

\begin{tabular}{|c|c|c|c|}
\hline Statement & $\begin{array}{l}\text { Right } \\
\%\end{array}$ & $\begin{array}{l}\text { Wrong } \\
\%\end{array}$ & $\begin{array}{l}\text { I do not know } \\
\%\end{array}$ \\
\hline 1. Human rights are only about Europeans. & $4.10 \%$ & $92.10 \%$ & $3.80 \%$ \\
\hline $\begin{array}{l}\text { 2. When their parents separate, children have the } \\
\text { right to say their opinion as to whom they prefer to } \\
\text { stay with. }\end{array}$ & $80.80 \%$ & $10.10 \%$ & $9.10 \%$ \\
\hline 3. Boys have more rights than girls. & $8.70 \%$ & $84.90 \%$ & $6.50 \%$ \\
\hline $\begin{array}{l}\text { 4. Parents can force their children to work to bring } \\
\text { money home. }\end{array}$ & $10.00 \%$ & $84.40 \%$ & $5.60 \%$ \\
\hline $\begin{array}{l}\text { 5. Parents have the obligation to send their } \\
\text { children at school. }\end{array}$ & $88.70 \%$ & $6.60 \%$ & $4.60 \%$ \\
\hline $\begin{array}{l}\text { 6. Children with special needs have the same rights } \\
\text { with other children. }\end{array}$ & $86.90 \%$ & $8.80 \%$ & $4.30 \%$ \\
\hline 7. Children have the right to have time to play. & $94.90 \%$ & $3.10 \%$ & $2.00 \%$ \\
\hline
\end{tabular}




\begin{tabular}{|c|c|c|c|}
\hline 8. Children are property (belong) of their parents. & $36.00 \%$ & $49.90 \%$ & $14.00 \%$ \\
\hline $\begin{array}{l}\text { 9. Children in every country should have the same } \\
\text { rights. }\end{array}$ & $90.70 \%$ & $5.30 \%$ & $4.00 \%$ \\
\hline $\begin{array}{l}\text { 10. Children have the right to speak their minds } \\
\text { about every matter concerning them. }\end{array}$ & $92.50 \%$ & $3.30 \%$ & $4.10 \%$ \\
\hline $\begin{array}{l}\text { 11. The state has an obligation to ensure that all } \\
\text { the children know their rights. }\end{array}$ & $87.60 \%$ & $3.60 \%$ & $8.80 \%$ \\
\hline $\begin{array}{l}\text { 12. Immigrant children have the right to enrol in } \\
\text { our schools. }\end{array}$ & $86.20 \%$ & $5.00 \%$ & $8.80 \%$ \\
\hline $\begin{array}{l}\text { 13. Children have the right to have free time to } \\
\text { deal with things that interest them. }\end{array}$ & $94.20 \%$ & $3.00 \%$ & $2.80 \%$ \\
\hline $\begin{array}{l}\text { 14. In some cases, parents have the right to hit } \\
\text { their children. }\end{array}$ & $25.00 \%$ & $63.90 \%$ & $11.10 \%$ \\
\hline 15. Girls have more rights than boys. & $3.50 \%$ & $89.80 \%$ & $6.70 \%$ \\
\hline
\end{tabular}

Finally, the students were asked how they would react if their best friend told them they are regularly abused by their family (Table 3$)$. The majority of students $(85.5 \%)$ responded with the option: "You should talk about it to your teacher! If you do not have the courage, I can go with you". However, $2.0 \%$ of the students chose the option: "Stop! I do not like sad stories", while $7.7 \%$ of the students would advise their friends not to talk about it to anyone else.

Table 3. Children's reactions when a friend reveals being abused

\begin{tabular}{|llll|}
\hline Children's reactions & $\begin{array}{l}\text { Elementary } \\
\text { Students } \\
\%\end{array}$ & $\begin{array}{l}\text { High-school/ } \\
\text { Lyceum Students } \\
\%\end{array}$ & $\begin{array}{l}\text { Total } \\
\%\end{array}$ \\
\hline Stop! I do not like sad stories. & 1.3 & 2.2 & 2.0 \\
\hline Do not talk to anyone in any case! & 14.7 & 11.4 & 12.4 \\
\hline $\begin{array}{l}\text { You should talk about it to your teacher! If you } \\
\text { do not have the courage, I can go with you. }\end{array}$ & 84.0 & 86.4 & 85.5 \\
\hline
\end{tabular}




\section{Adult Views And Levels Of Awareness About The Content In The Convention For The Rights Of The Child}

During telephone interviews with adults, the participants were asked about rights of the child of which they were aware (see Table 4). Most adults were aware of the right for a good standard of living (e.g. food, clothing, development, education, and health care). Table $4 \mathrm{a}$ refers to the rights that were mentioned regarding child protection rights. Table $4 \mathrm{~b}$ refers to children's participation rights and Table e $4 \mathrm{c}$ refers to children's provision rights identified by respondents.

Tables $4 a-4 c$ demonstrate that the majority of references to the rights of the child focused on the rights for provisions (education, health, food) and protection (from exploitation, violence). Specifically, $42.19 \%$ of respondents focused on the seven rights for provision, while $35.39 \%$ focused on the rights for protection. On the other hand, less participants (only 22.19\%) referred to the rights for participation (e.g. right to express one's opinion, right to information). This indicates that while these members of Cypriot society are aware of providing education, protection and care of children, there appears to be less awareness of children's participation rights including the right to an opinion and to be aware their rights. Similar findings emerged from personal interviews and focus groups. However, the university educated participants referred to more rights and had a stronger opinion about them. 
Table 4a. Adults' references to child protection rights

\begin{tabular}{|c|c|}
\hline Protection rights & $\begin{array}{l}\% \text { of } \\
\text { reference }\end{array}$ \\
\hline Discrimination (Gender, religion, race, nationality, property, etc.) & 2.11 \\
\hline Adults should see the best interest of the child. & 0.11 \\
\hline The state must ensure the rights of the child. & 1.50 \\
\hline The family must ensure the rights of the child. & 1.39 \\
\hline The right to life & 6.21 \\
\hline To stay with their parents unless this is opposite to their interests & 0.11 \\
\hline Protection from violence, neglect, or exploitation & 0.55 \\
\hline Protection from child labor and economic exploitation & 1.11 \\
\hline Drugs & 2.11 \\
\hline Sexual violence and exploitation & 3.83 \\
\hline Other forms of exploitation & 4.83 \\
\hline Torture and deprivation of freedom (kidnapping) & 0.22 \\
\hline Freedom from war and participation in hostilities & 0.17 \\
\hline Re-examination of the concept of child-victim & 0.11 \\
\hline Re-examination of foster care & 0.44 \\
\hline Justice & 1.00 \\
\hline State laws to protect the child & 0.28 \\
\hline Alternative custody (when no parents) & 7.99 \\
\hline Adoption & 0.11 \\
\hline Special care for refugees & 0.17 \\
\hline Protection from abduction & 0.17 \\
\hline Responsibility and support from parents & 0.39 \\
\hline Family reunion & 0.28 \\
\hline Implementation and control rights & 0.22 \\
\hline Total & $35.39 \%$ \\
\hline
\end{tabular}


Table 4b. Adults' references to children's participation rights

\begin{tabular}{|ll|}
\hline Right to participation & $\begin{array}{l}\text { \% of } \\
\text { references }\end{array}$ \\
\hline Name and nationality & 0.44 \\
\hline Preservation of identity, nationality & 0.39 \\
\hline Minorities: the right to speak their language, traditions etc & 0.94 \\
\hline Freedom of opinion & 0.06 \\
\hline Freedom of expression & 7.10 \\
\hline Freedom of religion & 6.43 \\
\hline Choice of friends & 3.44 \\
\hline Right to information & 2.44 \\
\hline Respect of privacy & 0.78 \\
\hline Awareness of rights & 0.17 \\
\hline & $\mathbf{2 2 . 1 9 \%}$ \\
\hline Total
\end{tabular}

Table 4c. Adults' references to the children's rights to provision

\begin{tabular}{|lc|}
\hline Provision rights & \multicolumn{2}{c|}{$\begin{array}{l}\text { \% of reference } \\
\text { Special education }\end{array}$} & 0.61 \\
\hline Health care & 11.43 \\
\hline Social welfare & 0.83 \\
\hline Standard of living: food, clothes, development & 12.15 \\
\hline Education & 11.59 \\
\hline Education: skill development, personality, respect for human rights & 2.00 \\
\hline Free time and entertainment & 3.55 \\
\hline Total & $\mathbf{4 2 . 1 9 \%}$ \\
\hline
\end{tabular}

For some participants, especially those without university education, they appeared to have difficulty understanding the term 'children's rights' and held negative views in accepting children's rights, per se. More specifically, one participant (40 years-old driver / high-school 
graduate) said that "our society gets worse because we allow children to have many rights and in the end, they turn against us" (meaning adults). Another participant (45 year-old waiter / high-school graduate) compared his generation to the new generation arguing that "teenagers who just sleep all day and night, and have no responsibilities." According to the same participant, "when I was their age, I was working during my free time."Furthermore, with regard to the right of freedom of expression, some participants claimed that such right leads to the "abuse of adults" kindness" and "disrespect to the oldest generation by youngsters who want to have an opinion about everything. Some decisions are only to be taken by adults and not by children" (32 year-old civil engineer / university graduate). This statement supports the idea that there is a need for further information on issues related to children's rights.

Interviews with participants indicated that they knew little about the governing bodies responsible for the protection of children's rights. The participants were asked whether they were aware of the Office of the Commissioner for Children's Rights. Social work students were the only ones who appeared to be fairly informed (see Table 5). Those who were aware of the Commissioner for Children's Rights were informed about it from television.

Nevertheless, when questioned about the responsibilities of the Commissioner, they could not provide any information. Of other adults who participated in the survey, only one teacher clearly stated that she was aware of the Office of the Commissioner because they had sent a greeting card to her school. 
Table 5. Adult awareness about children's rights and their protection

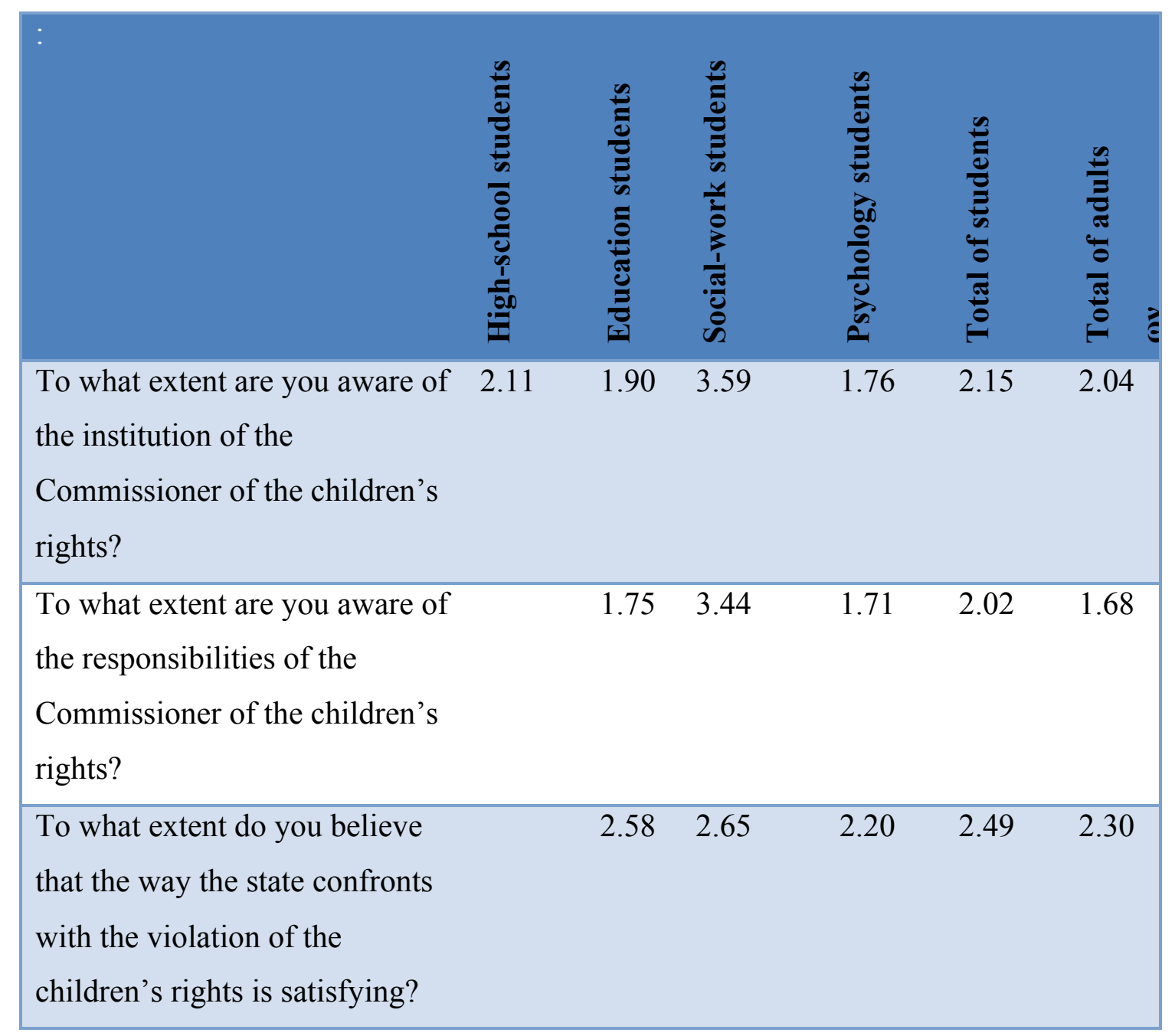

\section{Views On the Extent to which Children's Rights are Safeguarded}

An additional objective of this study was to examine societal views regarding the extent to which children's rights are safeguarded. Survey results show that the highschool/lyceum students believe to a greater extent that children's rights are safeguarded, in comparison with university students and other adults (see Table 6). All groups of students who participated in the survey agreed that the rights of Greek-Cypriot children without disabilities are safeguarded to a greater extent than the rights of immigrant children. Also, all adult groups who participated in the survey believed that children's rights are protected to a greater extent in Europe than in Cyprus.

Some participants were quite positive about the stance of the State towards children's rights. For example, some respondents noted that some children are granted free medical care 
by the State. Other individuals also agreed with this view and added that the new public school textbooks for the module 'Language and civilisation' recently introduced in primary schools focus on intercultural dialogue and anti-racism, while promoting the acceptance of all.

Table 6. Society's views about the extent to which children's rights are safeguarded

\begin{tabular}{|c|c|c|c|c|c|c|}
\hline $\begin{array}{l}\text { According to your opinion, } \\
\text { to which extent are } \\
\text { children's rights } \\
\text { safeguarded: }\end{array}$ & 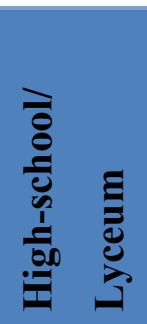 & 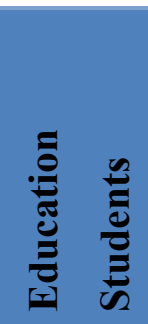 & 范 & 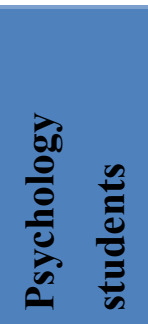 & $\stackrel{\frac{0}{0}}{\stackrel{0}{0}}$ & 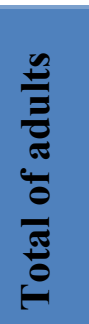 \\
\hline - immigrant children & 3.20 & 2.69 & 2.94 & 2.71 & 2.73 & 2.73 \\
\hline $\begin{array}{l}\text { - children coming from single- } \\
\text { parent families }\end{array}$ & 3.61 & 3.28 & 3.66 & 3.18 & 3.32 & 3.23 \\
\hline - children with disabilities & 3.62 & 3.18 & 3.44 & 3.00 & 3.18 & 2.77 \\
\hline $\begin{array}{l}\text { - Greek-Cypriot children } \\
\text { without disabilities }\end{array}$ & -- & 3.68 & 4.19 & 3.59 & 3.75 & \\
\hline $\begin{array}{l}\text { In your opinion, to what } \\
\text { extent are children's rights } \\
\text { safeguarded in Cyprus? }\end{array}$ & 2.81 & 2.78 & 2.68 & 2.30 & 2.65 & 2.60 \\
\hline $\begin{array}{l}\text { In your opinion, to what } \\
\text { extent are children's rights } \\
\text { safeguarded in Europe? }\end{array}$ & 3.31 & 3.35 & 3.34 & 3.08 & 3.28 & 3.19 \\
\hline
\end{tabular}

\section{Reports of Human Rights Violations in Accessing State Services}

Adults as well as students were asked whether their rights had been violated when they were children. The group with the lowest percentage claiming to have experienced violations of their rights during their childhood was university student (19.3\%). Nevertheless, 
university students stated to a greater degree than the high school/lyceum students who participated in this research $(47.1 \%)$ that they had friends whose rights had been violated. From the same sample of university students, only $2.6 \%$ responded that as children, they had reported human rights violations when accessing State services when they were children, although they were not asked to specify the particular service.

$40.3 \%$ of adult repondents believed that their rights had been violated when they were children (See Table 7). Only 1.2\% of these individuals whose rights were violated when accessing services appealed to State services responsible for the defense of their rights.

Discussion regarding this finding with interview participants turned to the Turkish invasion in Cyprus that took place in 1974, when many of these adults were children, who suggested that this may have been a contributing factor to the violation of their rights as children.

Table 7. Percentages regarding the violation of the participants' rights during their childhood

\begin{tabular}{|llllllll|}
\hline & Yes & No & Do not & Yes & No & Do not \\
& & & know & & & know \\
\hline $\begin{array}{l}\text { Do you believe that your rights } \\
\text { were violated during your }\end{array}$ & $31.1 \%$ & $40.9 \%$ & $28.0 \%$ & $56.8 \%$ & $36.4 \%$ & $6.7 \%$ \\
childhood? & & & & & & & \\
\hline $\begin{array}{l}\text { Do you believe that you have } \\
\text { friends whose rights had been } \\
\text { violated during their childhood? }\end{array}$ & $75.8 \%$ & $12.4 \%$ & $11.9 \%$ & $71.3 \%$ & $25.9 \%$ & $2.8 \%$ \\
\hline $\begin{array}{l}\text { Have you ever referred to state } \\
\text { services responsible for the }\end{array}$ & $2.6 \%$ & $96.4 \%$ & $1.0 \%$ & $2.7 \%$ & $96.9 \%$ & $0.4 \%$ \\
restoration of children's rights? & & & & & & & \\
\hline
\end{tabular}

The triangulation of our interview data with the results of this questionnaire indicate that most people are reluctant to report cases of violation of children's rights to the responsible State departments, either because of fear of possible personal consequences or because they do not want to be identified as the ones who filed the complaint. More specifically, our data indicates that teachers are the ones more willing to file complaints. 
Nevertheless, they did so only when the situation reached the worst case scenario. For example, one teacher reported that a mother went to school and disclosed (to the teachers) that her husband was abusing her daughter and that the girl was full of bruises. The teachers reported the case to the police who turned to the Welfare Office. The Welfare Office removed the children from the family for some time and provided them with shelter at a local organization. In this case, it appeared that the mother wanted to report to state services that her husband was abusing her children, but was afraid to do so; her only option appeared to be reporting the case to her children's school.

In another account reported by a teacher, a primary-school child was living with his father who neglected him since he had remarried. The child complained to his teacher that he was often left alone at their house and that he was afraid. The teacher reported the case to the Welfare Office.

The final account concerns a child that had been sexually abused by one of her relatives. She was afraid that it what would happen again if she reported the case due to the fact that the molester was a person in her family. The girl reported that she was aware of another child being abused by his parents who were well educated and had a high-rank in society. This girl wondered whether anonymity is guaranteed when you file a complaint and whether the parents of this child would be persuaded (if the case was reported) due to their social rank.

\section{Challenges For Children's Rights in Cyprus}

The participants interviewed for this study were asked to express their opinion about the major problems facing Cypriot society regarding children's rights. The main issues they raised were racism and marginalisation, abuse, and lack of support by the State.

\section{Racism and marginalisation}

The participants referred to the problem of racism and marginalisation by criticizing the ways in which children from foreign countries are treated. They also reported the marginalization of those who come from poor countries. On the other hand, some participants reported racism against Cypriot children by immigrants. Some claimed that immigrant students create 'cliques' in and out of schools in order to bully and marginalize Cypriot born 
children. In the same context, some participants indicated that some children are marginalized because of their disability (e.g. physical, mental, sensory). These responses suggest that racism and marginalization are major issues that could be addressed in policies combating the violation of children's rights.

\section{Failure to provide adequate services by the State}

Study participants argued that Cypriot schools do not provide adequate support to children who face learning difficulties or to children who have been identified as having disabilities (in order to qualify for support according to the law). They argued that at times, minor learning problems become larger over a short period of time. Furthermore, the participants discussed the lack of specialists in mainstream schools (i.e. children psychologists, sociologists, social workers, etc).

\section{Lack of support by the State}

Participants reported that the State does not support rural families and low income families. Consequently, children in rural areas may have far fewer opportunities than urban children. Additionally, if their parents are less educated than those who live in the city, they may fail to provide them any further support. According to some participants, the State has not made children's rights widely known and has not adequately informed citizens about what to do in cases of children's rights violations.

\section{Other problems}

Participants identified multiple freedoms afforded to children as a societal problem. It is noteworthy that these participants claimed that the current research study contributed to this situation. They argued, for example, that children do not listen to their parents and have an opinion about everything. They also cautioned that as long our society promotes children's freedom of expression, things will get much worse. Some participants stated that in today's society, children have more rights than their parents, teachers and adults in general, and they felt that children often abuse these rights. They also reported examples of child gangs who steal or destroy the properties of unsuspecting citizens, children who play football and hit their balls on parked cars, children who make excessive noise and, when asked by adults to be more quietly, children who behave rudely. While these examples were mentioned as 
related to the rights of children, they are a sign of the limited understanding of children's rights with some of the participants.

\section{Conclusions}

The purpose of this study was to examine the views and awareness levels of members of Cypriot society in relation to the UN Convention on the Rights of the Child. Results indicate that primary and secondary school children appear to be aware that children have rights. However, perceptions such as "children are the property of their parents" and "parents have the right to hit their children" are widely accepted among this group. Such perceptions come in a vertical conflict with the vision of the child as a distinct and autonomous personality with inherent rights and dignity introduced by the Convention on the Rights of the Child. High school students were aware of the right to freedom of expression, which they considered as an important right for them, but they did not seem to have such intense views regarding the application of freedom of expression in specific situations. From the point of view of adults, they seemed to know many of the child's rights, particularly those in the Pillar of Benefit area (e.g. education, entertainment). However, it appears that the competencies of the various bodies related to children's rights (e.g. Welfare Office, Commissioner for the Protection of Children's Rights, Police) are not clear in society and there is confusion among citizens about the responsibilities and competences of each institution.

Comparing the views of Cypriots in this study with other European studies of these issues, it seems that in some respects, the views are similar (e.g. knowledge of children's rights) while in other ways, it seems that European studies indicate evidence of more sensitivity to issues such as drugs, violence against children, and sexual exploitation of children. (Eurobarometer, 2008; Casas et al., 2006).

Furthermore, levels of awareness of children's rights seem to differ mainly in adult groups; namely, those without university education seemed to have difficulty understanding the term 'children's rights' and were resistant to the notion that children have rights. This finding points to the need to further inform some groups on issues related to the rights of the child. 
The study also examined views held by study participants regarding State efforts to safeguard children's rights. Given the results of this study, a number of suggestions for action to improve children's rights in Cyprus include: to widely inform children about their rights through celebrities (e.g. singers, actors, football players) who often act as role models for children; using Facebook pages set by the Office of the Commissioner for the Protection of the Rights of the Child; through visits to schools, and by providing seminars to students. In addition, parent's education regarding children's rights could also be promoted by the State.

The analysis indicates that it appears that the responsibilities of the various State departments dealing with the rights of the child are not clear to participants in the study (e.g. Social Welfare Office, Commissioner for the Protection of the Rights of the Child, Police). During the interviews, for example, some of the participants reported cases in which citizens were redirected elsewhere (eg. police) when they called one of the above services

In addition, State departments in Cyprus that receive complaints about child abuse should provide 24 hour a day service. As mentioned in the interviews, the Welfare Office in Cyprus closes at 14:15 each day; no reports can be filed after that time. Services that exclusively handle issues regarding the rights of the child could operate 24 hours a day.

Moreover, the State could also create a specific Commission in the Parliament on the Protection of the Rights of the Child (or a Sub-Committee of the existing Commission of Human Rights); create an independent body that could deal with these issues and that would have the power to act ex officio. Finally, the State could reduce the bureaucracy involved in children's rights matters and establish partnerships with other countries in order to examine other ways of safeguarding the protection of the children's rights through a transnational forum for discussion on the rights of the child. 


\section{References}

Angelides, P. \& Michaelidou, A. (2009). The deafening silence: Discussing children's drawings for understanding and addressing marginalisation. Journal of Early Childhood Research, 7(1), 27-45.

Angelides, P., Charalambous, C., \& Vrasidas, C. (2004). Reflections on policy and practice of inclusive education in pre-primary schools in Cyprus. European Journal of Special Needs Education, 18(2), 211-223.

Angelides, P. (2004). Towards inclusive education in Cyprus? International Journal of Inclusive Education, 8(4), 407-422.

Bosisio, R. (2013). Children's right to be heard: What children think. The International Journal of Children's Rights, 20(1), 141-154.

Casas, F. et al. (2006). Children's rights from the point of view of children, their parents and their teachers: A comparative study between Catalonia (Spain) and Il Molise (Italy). The International Journal of Children's Rights, 14(1), 1-75.

Deb, S. \& Mathews, B. (2012). Children's rights in India: Parents' and teachers' attitudes, knowledge and perceptions, The International Journal of Children's Rights, 20 (1), 241-264.

Eurobarometer (2008). The rights of the child: Analytical report. Survey conducted by the Gullup Organization, Hungary upon the request of Directorate-General for justice, freedom and security, EU.

Hadjivasilis, M. (2009). Offence is the corruption of girls up to 16 years old. Fileleftheros Newspaper, Friday 12 June. [In Greek]

Karaman-Kepenekci, Y. (2006). A study of university students' attitudes towards children's rights in Turkey. The International Journal of Children's Rights, 14(3), 307-318.

Kassinidou, K. (2009). The 'law of silence' has broken in New Eleousa: 'Flaming' report from the Ministry of Labour. Fileleftheros Newspaper, Wednesday 25 March. [In Greek]

Khoury-Kassabri, M. \& Ben-Arieh, A. (2009). School climate and children's views of their rights: A multi-cultural perspective among Jewish and Arab adolescents. Children and Youth Services Review, 31(2), 97-103.

Kyriakidou, C. (2009). Tracking down abused children in schools. Fileleftheros Newspaper $\Phi \imath \lambda \varepsilon \lambda \varepsilon \dot{v} \theta \varepsilon \rho \circ \varsigma$, Saturday 21 February. [In Greek] 
Lundy, L., Kilkelly, U., Byrne, B. (2013). Incorporation of the United Nations Convention on the rights of the child in law: A comparative review. The International Journal of Children's Rights, 21(3), 442-463.

Margolin, C. R. (1982). A survey of children's views on their rights. Journal of Clinical Child Psychology, 11(2), 96-100.

Messiou, K. (2006). Conversations with children: Making sense of marginalization in primary school settings. European Journal of Special Needs Education, 21(1), 3954.

Panagi, M. (2009a). Shock for child abuse. Fileleftheros Newspaper, Friday 29 March. [In Greek]

Panagi, M. (2009b). Marginalising disabled children: Koursoumba is berserk with pre-school teachers. Fileleftheros Newspaper, Saturday 6 June. [In Greek]

Quennerstedt, A. (2016). Children's human rights at school - as formulated by children. The International Journal of Children's Rights, 24 (3), 657 - 677.

United Nations (2002). General comment No 2: The role of independent national human rights institutions in the promotion and protection of the rights of the child. $\mathrm{CRC} / \mathrm{GC} / 2002 / 2$

United Nations (2003). General comment No 5: General measures of implementation of the convention on the rights of the child (arts. 4, 42 and 44, para. 6). CRC/GC/2003/5.

Van Daalen, E., Hanson, K. \& Nieuwenhuys, O. (2016). Children's rights as living rights: The case of street children and a new law in Yogyakarta, Indonesia. The International Journal of Children's Rights, 24(4), 803-825.

Wrightsman, L., et al. (1975). Conceptualization and measurement of attitudes toward children's rights. ERIC, ED 118262, PS 008360. 